Occurrence of Ratel Mellivora capensis is supplemented by a few disjunctive ecological evidences of individuals from different parts of the world indicating a poorly known distribution status. Though the OPEN ACCESS global population trend of Ratels (c) (1) remains unknown, the species is listed as Least Concern due to its wide range of distribution, although they are considered to be rare and occur at low densities in most parts (Begg et al. 2008) the threats to localized population have occurred globally.

Within the boundaries of India, some sources have ascertained the presence of Ratels in western and central India (Prater 1971; Gupta et al. 2012) which includes states of Madhya Pradesh (Brander 1991), Gujarat and Rajasthan (Sharma 2013) and in eastern India the state of Odisha (ORA 2011). A study in western India also reported an average density of $5.48 \pm 4.33$ animals $/ 100 \mathrm{~km}^{2}$ in summer and $6.43 \pm 2.79$ animals $/ 100 \mathrm{~km}^{2}$ in winter in Sariska Tiger Reserve (Gupta et al. 2012). Apart from a few occurrences that were reported by Karanth (1986) in Srinivasapura region of Kolar District in 1974 and by Kumara \& Singh (2007) in parts of Kolar District during early 1960s and Sathanur in 2003, and by Hussain (1999) in Tamil Nadu, the distribution status of Ratels in the southern part of the country remains inadequate. A recent report of occurrence in the southern Indian state of Karnataka was published by Gubbi et al. (2014) disclosing occurrence of Ratels in four ranges of Cauvery Wildlife

\section{A BADGER IN BANNERGHATTA: AN OPPORTUNISTIC RECORD OF THE RATEL MELLIVORA CAPENSIS (SCHREBER, 1776) (MAMmalia: Carnivora: Mustelidae) FROM KARNATAKA, INDIA}

\author{
Avinash Krishnan ${ }^{1}$, Sunil Panwar ${ }^{2}$, Aaranya Gayathri ${ }^{3}$, \\ Sagarika Phalke ${ }^{4}$ \& Dilip Abani Venkateshaiah ${ }^{5}$ \\ 1,3,4,5 A Rocha India, \#13, Kasserguppe village, Bilwardahalli, \\ Bannerghatta Post, Bengaluru, Karnataka 560083, India \\ ${ }^{2}$ Deputy Conservator of Forests, Bannerghatta National Park, \\ Karnataka Forest Department, Bengaluru, Karnataka 560083, India \\ 1 avinash.krishnan@arocha.org (corresponding author), \\ ${ }^{2}$ sunvetpanwar@rediffmail.com, ${ }^{3}$ aaranya.gayathri@arocha.org, \\ ${ }^{4}$ sagarika.phalke@arocha.org, ${ }^{5}$ dlpkmr777@gmail.com
}

Sanctuary of Karnataka viz.: Halagur, Hanur, Kaudalli and Malai Mahadeshwara Hills Ranges. We present here the first contemporary record of a Ratel which was camera trapped in the protected area of Bannerghatta National Park during the course of other research.

Study Area: Bannerghatta National Park (BNP) covering an area of ca. $256 \mathrm{~km}^{2}$ is located in the northern most tip of Eastern Ghats in the State of Karnataka, India. The park is linear in shape, extending not more than $5 \mathrm{~km}$ in width and is contiguous in the south-east with North Cauvery Wildlife Sanctuary (in Tamil Nadu) and in the south-west with Cauvery Wildlife Sanctuary (CWLS; in Karnataka). The forest predominantly comprises of tropical thorn scrub, dry and moist deciduous forest types characterized by Acacia chundra, Anogeissus

DOI: http://dx.doi.org/10.11609/jott.2587.8.5.8820-8823 | ZooBank: urn:Isid:zoobank.org:pub:CFAF7008-BF4B-47F9-A964-D3C880502747

Editor: Anonymity requested.

Date of publication: 26 May 2016 (online \& print)

Manuscript details: Ms \# 2587 | Received 27 February 2016 | Final received 11 May 2016 | Finally accepted 16 May 2016

Citation: Krishnan, A., S. Panwar, A. Gayathri, S. Phalke \& D.A. Venkateshaiah (2016). A badger in Bannerghatta: an opportunistic record of the Ratel Mellivora capensis (Schreber, 1776) (Mammalia: Carnivora: Mustelidae) from Karnataka, India. Journal of Threatened Taxa 8(5): 8820-8823; http://dx.doi.org/10.11609/ jott.2587.8.5.8820-8823

Copyright: @ Krishnan et al. 2016. Creative Commons Attribution 4.0 International License. JoTT allows unrestricted use of this article in any medium, reproduction and distribution by providing adequate credit to the authors and the source of publication.

Funding: The study was funded by A Rocha India under the directorate of Science and Conservation.

Conflict of Interest: The authors declare no competing interests.
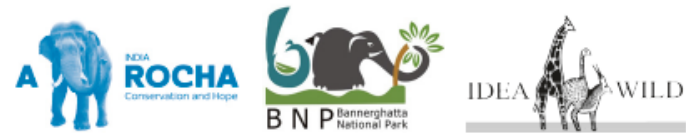

Acknowledgement: We would like to extend our sincere thanks to the Karnataka Forest Department of Bannerghatta National Park for their unstinted support. We acknowledge the support of Idea Wild (NPO) - USA for providing some of the camera-trap equipment, as part of a grant. The authors wish to thank Hima Bindu for helping with the GIS work. The first author would like to thank Dr. Jeremy Lindsell of A Rocha International, Prem Mitra, Aswath Honnavar and Surendra Varma for their reviews, support and encouragement. We are also grateful for an anonymous reviewer for inputs and suggestions on improving the quality of this manuscript. 
latifolia and Shorea robusta (Suresh \& Bhat 2000; Varma et al. 2009). BNP is inhabited by many faunal species including Asian Elephant Elephas maximus, Gaur Bos gaurus, Leopard Panthera pardus and Dhole Cuon alpinus (Singh 2008; Varma et al. 2009; Karikalan 2013). BNP, however experiences high anthropogenic pressures along the fringes from cattle grazing, sand-mining and fuel wood collection caused by approximately 130 settlements lying just within $5 \mathrm{~km}$ from the protected area boundary.

Methods: Two motion-triggered infra-red camera traps (Bushnell HD 8MP Trail Camera) were set to record the ranging patterns of a wild Tiger Panthera tigris that had been recently reported in BNP. Cameras were set along the likely travel routes of the Tiger in two of the wildlife ranges of BNP viz., Bannerghatta wildlife range and Harohalli wildlife range, in an opportunistic manner. In Harohalli wildlife range, the camera had a trap cycle of 13 days and were kept active throughout the day and night and were positioned at a vertical height of $45 \mathrm{~cm}$. The camera-trap was set to record $24 \mathrm{~h}$ a day and to take three images per detection with a delay of $5 \mathrm{~s}$ between images. The current location had a total sampling effort of 26 days.

Results: A camera set near the KaradikalMahadeshwara Elephant Corridor that connects Harohalli and Anekal wildlife ranges of BNP between 15 October 2015 and 10 November 2015 recorded images of a Ratel on 02 November 2015 at 00h31 (Image 1). The age and sex of this individual could not be determined.

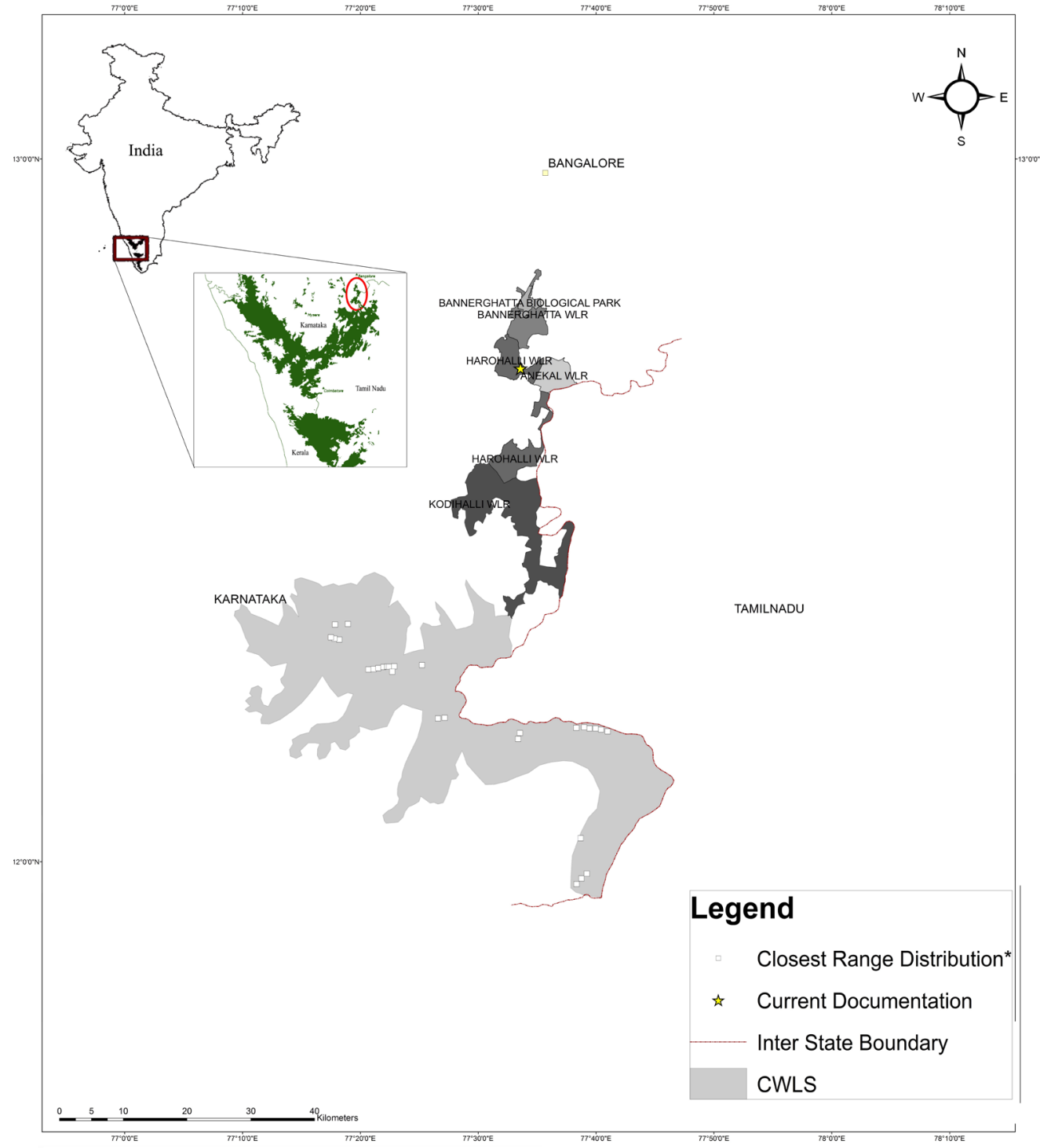

*approximate closest range distribution in CWLS obtained from Gubbi et al during January and March 2014
Figure 1. Spatial representation of the records of Honey Badger in 2014 and 2015 in Karnataka 


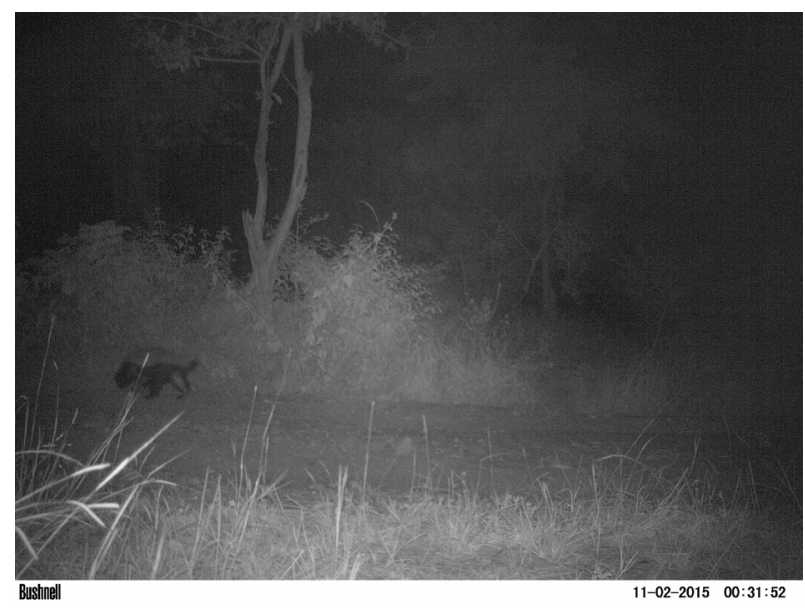

Image 1. Photographic record of a Ratel captured on a camera trap in BNP

The same camera also captured images of Tiger, Gaur and domestic cows.

Discussions: The forests of BNP are connected to the CWLS in the south-west which have had recent records of Ratels (Fig. 1). This suggests that Ratels could range throughout this area and occur regularly within BNP. Although a single observation is insufficient to establish a resident population of Ratels in BNP, it is clear that the habitat bears some of the ecological characteristics that may be conducive. Though the vegetation of the region is characterized by scrub and mixed deciduous forest with predominant occurrences of Anogeissus spp. and Acacia spp., BNP has an average ground cover of $62 \%$ (Varma et al. 2009) which may provide adequate microhabitats for these species, similar to another opportunistic report of an indirect evidence of Ratels in such type of a habitat (Joshi \& Andavan 2008). Moreover, BNP reports of a good diversity and occurrence of bamboo (Dendrocalamus spp.) thickets which could be a viable shelter for these small carnivores (Vanderhaar \& Hwang 2003). Gupta et al. (2012) reports that water bodies may have a positive correlation to the presence of Ratels. Two water bodies at a closest aerial distance of $400 \mathrm{~m}$ and $800 \mathrm{~m}$ from the point of photo-capture were noted, which may contribute to the viability of the habitat. Thereby, it can be assumed that scrub and deciduous vegetation may be conducive (Prater 1971; Menon 2014) for a species that ranges in dry habitats of Africa, Arabia, Iran and central India; and that BNP could possibly indicate a distribution of Honey Badgers in the contiguous stretch of the Eastern Ghats landscape.

On the other hand, an analysis of the spatial component of the photo-capture site, reveals that it lies in close proximity to the village of Jaipurdhoddi with an approximate distance of $1 \mathrm{~km}$ where concomitant cattle grazing has been reported by the local forest officials, to be intense along the trail path. Though a comparative study conducted by Gupta et al. (2012) reports that proximity to roads and villages may have a negative impact on habitat suitability for Ratels, the current documentation has been in a landscape much influenced by anthropogenic impacts. The northern and north-western margins of BNP are surrounded by highly human-dominated zones and Bangalore City lies at a distance of $22 \mathrm{~km}$ north of the protected area, thereby warranting further field studies in this region for effective long-term conservation of the species. Though some Ratels in Africa have been reported to raid poultry from nearby villages (Begg \& Begg 2002), no instances of such conflict caused by Ratels are known and forest officials have not seen the animal or recognized any evidences of Ratels in BNP prior to this record. Considering their habitat requirements and conflict prone behaviour, it could be a conservation concern and may warrant further studies on population dynamics and foraging behaviour in this region.

\section{References}

Begg, K. \& C. Begg (2002). The conflict between Beekeepers and Honey Badgers in South Africa: a Western Cape Perspective. The Open Country 4 (Summer): 25-36.

Begg, K., C. Begg \& A. Abramov (2008). Mellivora capensis. The IUCN Red List of Threatened Species 2008, e.T41629A10522766. www. iucnredlist.org. Downloaded on 21 November 2015; http://dx.doi. org/10.2305/IUCN.UK.2008.RLTS.T41629A10522766.en.

Brander, D. (1991). Wild Animals in Central India. Natraj Publishers, Dehradun, 276-277pp.

Gubbi, S., V. Reddy, H. Nagashettihalli, R. Bhat \& M.D. Madhusudan (2014). Photographic records of the Ratel Mellivora capensis from the southern Indian state of Karnataka. Small Carnivore Conservation 50: 42-44.

Gupta, S., K. Mondal, K. Sankar \& Q. Qureshi (2012). Abundance and habitat suitability model for Ratel (Mellivora capensis) in Sariska Tiger Reserve, Western India. Wildlife Biology in Practice 8(1): 1322; http://dx.doi.org/10.2461/wbp.2012.8.2.

Hussain, S. (1999). www.honeybadger.com/distribution.html. Downloaded on 18 November 2015.

Joshi, P. \& L.M. Andavan (2008). New sighting and distribution record of Ratel or Honey Badger (Mellivora capensis indica Kerr, 1792) in the Kachchh Forest of Gujarat. Tiger Paper 35(1): 12.

Karanth, K.U. (1986). Status of Wildlife and Habitat Conservation in Karnataka. Journal of the Bombay Natural History Society 83(supplement): 166-179.

Karikalan, V. (2013). Wildlife Management Plan for Bannerghatta National Park, 2013-14 to 2017-18. Government of Karnataka, ivpp.

Kumara, H. \& M. Singh (2007). Small Carnivores of Karnataka: Distribution and Sight Records. Journal of the Bombay Natural History Society 104 (2): 155-162.

Menon, V. (2014). Indian Mammals A Field Guide. Hachette Book Publishing India Pvt. Ltd., Manipal, 295-296.

[ORA] Odisha Reference Annual (2011). Flora and Fauna. Government of Odisha. http://odisha.gov.in/e-magazine/orissaannualreference/ ORA-2011/pdf/14-16.pdf. Downloaded on 25 November 2015. 
Prater, S. (1971). The Book of Indian Animals. Bombay Natural History Society/Oxford University Press, New Delhi, 162-163pp.

Sharma, G. (2013). A review on the Studies on Faunal diversity, status, threats and conservation of Thar Desert or Great Indian Desert Ecosystem. Biological Forum - An International Journal 5(2): 81-90.

Singh, V.V. (2008). Wildlife Management Plan for Bannerghatta National Park, 2008-09 to 2012-13. Government of Karnataka.

Suresh, H. \& H.R. Bhat (2000). Flora of Indian Institute of Science campus. Journal of Indian Institute of Science 80: 519-529.

Vanderhaar, J.M. \& Y.T. Hwang (2003). Mellivora capensis. Mammalian Species 721: 1-8.

Varma, S., V.D. Anand, K.G. Avinash \& M.S. Nishant (2009). Ecology, Conservation and Management of the Asian Elephant in Bannerghatta National Park, southern India. A Rocha India/ANCF: Asian Elephant Ecology and Conservation Reference Series No.1. A Rocha India and Asian Nature Conservation Foundation, Bangalore, 13-52. 